\title{
Production of Lectins from Marine Algae: Current Status, Challenges, and Opportunities for Non-Destructive Extraction
}

\author{
Intan Mariana Maliki, Mailin Misson (D), Peik Lin Teoh (D), Kenneth Francis Rodrigues \\ and Wilson Thau Lym Yong*(D)
}

Citation: Maliki, I.M.; Misson, M.; Teoh, P.L.; Rodrigues, K.F.; Yong, W.T.L. Production of Lectins from Marine Algae: Current Status, Challenges, and Opportunities for Non-Destructive Extraction. Mar. Drugs 2022, 20, 102. https://doi.org/ $10.3390 / \mathrm{md} 20020102$

Academic Editor: Hitoshi Sashiwa

Received: 25 December 2021

Accepted: 24 January 2022

Published: 26 January 2022

Publisher's Note: MDPI stays neutral with regard to jurisdictional claims in published maps and institutional affiliations.

Copyright: (C) 2022 by the authors. Licensee MDPI, Basel, Switzerland. This article is an open access article distributed under the terms and conditions of the Creative Commons Attribution (CC BY) license (https:// creativecommons.org/licenses/by/ $4.0 /)$.
Biotechnology Research Institute, Universiti Malaysia Sabah, Kota Kinabalu 88400, Sabah, Malaysia; imarianamaliki@gmail.com (I.M.M.); mailin@ums.edu.my (M.M.); peiklin@ums.edu.my (P.L.T.); kennethr@ums.edu.my (K.F.R.)

* Correspondence: wilsonyg@ums.edu.my

\begin{abstract}
Marine algae are an excellent source of novel lectins. The isolation of lectins from marine algae expands the diversity in structure and carbohydrate specificities of lectins isolated from other sources. Marine algal lectins have been reported to have antiviral, antitumor, and antibacterial activity. Lectins are typically isolated from marine algae by grinding the algal tissue with liquid nitrogen and extracting with buffer and alcohol. While this method produces higher yields, it may not be sustainable for large-scale production, because a large amount of biomass is required to produce a minute amount of compound, and a significant amount of waste is generated during the extraction process. Therefore, non-destructive extraction using algal culture water could be used to ensure a continuous supply of lectins without exclusively disrupting the marine algae. This review discusses the traditional and recent advancements in algal lectin extraction methods over the last decade, as well as the steps required for large-scale production. The challenges and prospects of various extraction methods (destructive and non-destructive) are also discussed.
\end{abstract}

Keywords: algal lectin; culture media; large scale production; marine algae; non-destructive extraction

\section{Introduction}

Macrophytic marine algae, also known as seaweeds, are nonvascular, multicellular, photosynthetic aquatic plants that live in the coastal regions of ocean waters, typically in intertidal or submerged reef-like habitats [1]. Seaweeds are classified into three major groups based on their pigment color: Chlorophyta (green seaweed), Phaeophyceae (brown seaweed), and Rhodophyta (red seaweed) [2]. Several types of valuable proteins, such as peptides, enzymes, glycoproteins, lectins, and mycosporine-like amino acids, are abundant in seaweeds, accounting for up to $50 \%$ of dry weight [2].

A "lectin" is a protein that possesses the ability to agglutinate red blood cells with known sugar specificity. When the sugar specificity is unknown, the protein is referred to as "hemagglutinin" [3]. Terrestrial plant lectins are typically found in seeds and other tissues and organs such as roots, tubers, bulbs, bark, leaves, and flowers [4]. In 1966, Boyd and his associates [5] discovered lectin in 24 algae species off the coast of Puerto Rico, which was the first discovery of lectin in marine algae. Since then, numerous studies on marine algal lectin have been published. Lectins are a type of non-immune protein or glycoprotein that can bind to carbohydrates or glycol components on cell surfaces reversibly [6,7]. Lectins are primary metabolites found in marine algae that play a role in physiological functions, including reproduction under normal growth conditions [3,7].

Traditionally, lectin was extracted from marine algae using mechanical and enzymatic methods. These methods were discovered to be laborious and time-consuming [8]. Therefore, rapid and high-throughput methods for lectin extraction are required for large-scale and sustainable production. Several protein extraction methods have since been published, 
including the enzyme-assisted method (EAE), the ultrasound-assisted method (UAE), and the supercritical fluid extraction method (SFE). While these methods were successful in isolating bioactive compounds from marine algae [9-12], there were few reports on lectin extraction specifically. Until recently, a revolutionary non-destructive lectin extraction approach known as cold steeping infusion (CSI) has been published [13]. This method enables the extraction of algal lectins from culture media without damaging the marine algae, and allows the algae to revert to their metabolic state following extraction. Nevertheless, reports on large-scale production of marine algal bioactive compounds, particularly algal lectin, are scarce. Therefore, more research into the nature and biology of marine algae, and advancements in extraction technologies, are required to better understand the challenges in algal lectin extraction and achieve successful production at larger scales for medical, pharmaceutical, and biotechnological applications.

\section{Marine Algae-A Vital Source of Lectins}

Marine algae are renowned as a rich source of protein and are regarded as an alternative source of protein due to their high protein and amino acid content [14]. Apart from that, marine algae contain a high concentration of secondary metabolites, which can be converted into a variety of bioactive compounds with diverse biological activities. The protein content of various types of marine algae differs depending on their classification. Brown algae has a low protein content in dry matter basis (DMB) of around 24-166 g/ kg, whereas green and red algae have higher protein contents of 32-352 g/ kg and 64-376 g/ kg, respectively [15]. However, these values can vary depending on the genus species, growing environment, and harvest time [16,17]. Table 1 shows the protein composition of various marine algae species on a dry matter basis.

Table 1. Protein composition extracted from various marine algae on a dry matter basis (DMB).

\begin{tabular}{|c|c|c|}
\hline Species & Protein Content (Dry Matter Basis) & Reference \\
\hline Laminaria hyperborea $^{2}$ & $50.2 \pm 2.8$ & [18] \\
\hline Laminaria digitata $^{1}$ & 15.9 & [19] \\
\hline Ulva lactuca $^{2}$ & $86.5 \pm 3.3$ & {$[18]$} \\
\hline Ulva rigida $^{2}$ & $112.0 \pm 5.8$ & {$[20]$} \\
\hline Ulva rotundata ${ }^{2}$ & $100.1 \pm 4.9$ & [20] \\
\hline Palmaria palmata $^{2}$ & $122.6 \pm 3.1$ & [18] \\
\hline Kappaphycus sp. ${ }^{2}$ & $25-38$ & [21] \\
\hline Porphyra spp. ${ }^{2}$ & 429.9 & [22] \\
\hline Porphyra acanthophora ${ }^{1}$ & 16.5 & [23] \\
\hline
\end{tabular}

Lectins are carbohydrate-binding proteins that are not enzymes or antibodies [24,25]. They can form a relatively strong complex due to their specific affinities to specific glycan structures [26,27]. Stillmark [28] first discovered lectins in the seeds of Ricinus communis in 1888 , and he went on to be a pioneer in isolating lectins from plant seeds and roots, bacteria, algae, fungi, and mammalian cell membranes. Lectins have gained popularity in biological and biomedical research as the most flexible group of proteins with immense potential, as they play a significant role in cell-cell recognition and drug delivery [29]. Their ability to decipher glycocodes, and their carbohydrate-binding specificity, molecular structure, and biochemical properties, contribute to their high level of biological activity [29]. Lectins have been found in most classes and families of organisms studied thus far, indicating that they are widely distributed in a diverse range of organisms [24]. Marine algal lectins have a proteinaceous content comparable to terrestrial plants. In general, they have low molecular masses, no affinity for monosaccharides, divalent cation-independent hemagglutination, and a high specificity for complex oligosaccharides, often glycopro- 
teins [24,30]. Marine algae have also been reported to have anti-cancer, antiviral, and antibacterial properties [31-35]. The majority of anti-cancer properties are activated by binding on cancer cell membranes, resulting in cytotoxicity, apoptosis, and tumor growth inhibition [31]. On the other hand, algal lectins have antiviral properties due to their specific binding properties to carbohydrate structures that allow them to inhibit virus replication via interactions with viral envelope proteins [36].

Marine algae are an excellent source of novel lectins, with examples being Griffithsin from the red alga Griffithsia [37], SfL-1 and SfL-2 from Solieria filiformis [32], and HRL40 from Halimeda renschii [38]. More research into the biotechnological functions of lectins has begun, including antiviral activity against the hepatitis $C$ virus (HCV) [35], induced cell death in human cancer cells [34], inhibition of streptococcal adherence by algal lectin extracted from Bryothamnion triquetrum and Bryothamnion seaforthii [30], and mitogenic activity of mouse spleen T lymphocytes [39]. The emergence of the novel coronavirus SARS-CoV-2 in December 2019 has raised awareness about the importance of antiviral agents and therapeutic concepts in controlling the outbreak, as vaccination is not always readily available. Many studies have shown that lectins can prevent the influenza virus from entering host cells, making them a promising candidate [33,40-42]. Table 2 depicts various marine algae species, their corresponding lectins, and their actions such as anticancer, antivirus, and drug delivery. For example, algal lectin KAA-2 from Kappaphycus alvarezii has been found to inhibit influenza virus entry into mammalian cells by binding directly to high mannose (HM)-type $N$-glycans of the viral envelope hemagglutinin (HA) [33]. HRL40 lectin, isolated from green alga Halimeda renschii, was observed to prevent influenza virus (A/H3N2/Udorn/72) infection in NCI-H292 cells via high-affinity binding to the viral envelope hemagglutinin at a half-maximal effective dose (ED50) of $2.5 \mathrm{nM}$ [38].

Table 2. Marine algae species and their lectins and specificity, extraction, and purification methods, and reported applications.

\begin{tabular}{|c|c|c|c|c|c|c|}
\hline Species & Lectin & Specificity & Extraction & Purification & Applications & Reference \\
\hline Eucheuma serra & ESA & Mannose & $\begin{array}{l}\text { Phosphate } \\
\text { buffer }\end{array}$ & $\begin{array}{l}\text { Ethanol } \\
\text { precipitation, } \\
\text { fast protein } \\
\text { liquid chro- } \\
\text { matography } \\
\text { (FPLC) }\end{array}$ & $\begin{array}{c}\text { Anticancer } \\
\text { (apoptosis on cancer } \\
\text { cell lines such as OST, } \\
\text { LM8, Colo201 and } \\
\text { HeLa); antibacterial }\end{array}$ & {$[31,33,34,43,44]$} \\
\hline Solieria filiformis & $\begin{array}{l}\text { SfL-1 } \\
\text { SfL-2 }\end{array}$ & Mannose & $\begin{array}{c}\text { Grinding with } \\
\text { liquid nitrogen, } \\
\text { phosphate } \\
\text { buffer }\end{array}$ & $\begin{array}{l}\text { Ammonium } \\
\text { sulfate } \\
\text { precipitation, } \\
\text { ion-exchange } \\
\text { chromatogra- } \\
\text { phy }\end{array}$ & $\begin{array}{c}\text { Anticancer } \\
\text { (apoptosis on cell } \\
\text { lines Colo201, LM8 } \\
\text { and mouse colon26 } \\
\text { adenocarcinoma); } \\
\text { induce Th2 immune } \\
\text { responses in mouse } \\
\text { splenocytes; } \\
\text { anti-depressant }\end{array}$ & {$[32,43,45-47]$} \\
\hline $\begin{array}{l}\text { Amansia } \\
\text { multifida }\end{array}$ & $\mathrm{AmL}$ & $\begin{array}{l}\text { Avidin, fetuin, } \\
\text { mannose }\end{array}$ & $\begin{array}{l}\text { Grinding with } \\
\text { liquid nitrogen, } \\
\text { sodium } \\
\text { phosphate }\end{array}$ & $\begin{array}{l}\text { Ammonium } \\
\text { sulfate } \\
\text { precipitation, } \\
\text { ion-exchange } \\
\text { chromatogra- } \\
\text { phy }\end{array}$ & $\begin{array}{l}\text { Anti-inflammatory } \\
\text { action (reducing } \\
\text { edema formation, } \\
\text { leukocyte migration, } \\
\text { and reducing level of } \\
\text { proinflammatory } \\
\text { cytokines) }\end{array}$ & {$[46,48]$} \\
\hline
\end{tabular}


Table 2. Cont.

\begin{tabular}{|c|c|c|c|c|c|c|}
\hline Species & Lectin & Specificity & Extraction & Purification & Applications & Reference \\
\hline $\begin{array}{l}\text { Kappaphycus } \\
\text { alvarezii }\end{array}$ & KAA-2 & $\begin{array}{l}\text { High mannose } \\
\text { glycan }\end{array}$ & $\begin{array}{c}\text { Homogenization, } \\
\text { ethanol }\end{array}$ & $\begin{array}{c}\text { Ethanol } \\
\text { precipitation, } \\
\text { size exclusion } \\
\text { chromatogra- } \\
\text { phy, ion } \\
\text { exchange chro- } \\
\text { matography }\end{array}$ & $\begin{array}{c}\text { Anti-influenza } \\
\text { (inhibits influenza } \\
\text { virus propagation by } \\
\text { directly binding to } \\
\text { high mannose } \\
\text { glycans on the } \\
\text { envelope } \\
\text { glycoprotein } \\
\text { hemagglutinin) }\end{array}$ & {$[33,49]$} \\
\hline Griffithsia sp. & Griffithsin & Mannose & $\begin{array}{l}\text { Freeze drying, } \\
\text { distilled water }\end{array}$ & $\begin{array}{l}\text { Ammonium } \\
\text { sulfate } \\
\text { precipitation, } \\
\text { hydrophobic } \\
\text { interaction chro- } \\
\text { matography }\end{array}$ & $\begin{array}{c}\text { Antiviral (targeting } \\
\text { high mannose arrays } \\
\text { present on } \\
\text { pathogenic } \\
\text { enveloped virus such } \\
\text { as HIV, } \\
\text { coronaviruses, } \\
\text { hepatitis C viruses } \\
\text { and Japanese } \\
\text { encephalitis virus }\end{array}$ & {$[35,37,50-54]$} \\
\hline $\begin{array}{l}\text { Bryothamnion } \\
\text { triquetrum } \\
\text { Bryothamnion } \\
\text { seaforthii }\end{array}$ & $\begin{array}{l}\text { BTL } \\
\text { BSL }\end{array}$ & Mucins & $\begin{array}{l}\text { Grinding with } \\
\text { liquid nitrogen, } \\
\text { sodium } \\
\text { phosphate }\end{array}$ & $\begin{array}{l}\text { Ammonium } \\
\text { sulfate } \\
\text { precipitation, } \\
\text { ion exchange } \\
\text { chromatogra- } \\
\text { phy }\end{array}$ & $\begin{array}{c}\text { Cancer biomarkers, } \\
\text { drug delivery }\end{array}$ & {$[55-57]$} \\
\hline
\end{tabular}

\section{Challenges in Algal Lectin Extraction}

Algal lectins and their extraction are a relatively understudied research area compared to mushrooms and higher plants such as kidney beans and wisteria plants. It is critical to have a high level of accessibility to the protein molecules in the cells to extract the protein successfully. The presence of cell wall mucilage, however, limits the efficiency of algal lectin extraction $[2,20,58]$. The presence of cell walls and intracellular polysaccharides causes high viscosity and ionic interaction, which impedes extraction [58]. Another factor that may influence the extraction process is the morphology of the marine algae themselves; for example, marine algae with tougher thallus may require more processing [59]. To maximize lectin yield from marine algae, raw biomass should be freeze dried prior to extraction or used fresh as soon as possible to avoid protein degradation [2].

Traditional methods for extracting algal protein include aqueous, acidic and alkaline methods, followed by several rounds of centrifugation and recovery using techniques such as ultrafiltration, precipitation, or chromatography $[8,60]$. Other methods, such as two-phase alkali and acid treatment, have also been demonstrated to be effective in extracting proteins from marine algae. With regards to algal lectin extraction specifically, some common traditional methods include mechanical (maceration, physical grinding with liquid nitrogen) and enzymatic procedures [8], and the majority of research to date has used the methods listed in Table 2.

Although these methods yielded promising results, there were some concerns, such as the possibility that traditional mechanical and enzymatic extraction methods may affect the extracted algal lectin due to the release of proteases from cytosolic vacuoles [61]. Aside from that, these methods are time-consuming and labor-intensive, requiring significant improvements in cell disruption and extraction processes. Conventional methods of algal protein extraction are both resource inefficient and environmentally unfriendly, as algae by-products are often discarded after processing [8]. When the process is scaled up, the problem becomes much larger, and the waste becomes even more pronounced. Hence, 
improvements in terms of time, cost, energy consumption, and health hazard management towards humans and the environment are required.

Marine algae as a source of lectin require a concentrated form of high-quality extracts for various downstream applications. Isolating and purifying lectin from marine algae has been accomplished primarily through manipulation of initial extraction methods, as other methods have not been explored further. The purification of novel lectins is also a challenge due to their unknown physicochemical properties. The final application, production scale, and initial extraction method should all be taken into account when selecting a lectin purification method [59].

\section{Lectin Production from Algal Cell Suspension}

Suspension culture, also known as cell suspension, is a useful method for providing materials for high-throughput studies such as plant secondary metabolite production, allowing a large number of cells to be simultaneously screened for desired traits and facilitating research on a physiologically and biochemically homogenous population of cells $[62,63]$. Cell suspension cultures have been used to produce lectins in higher plants, including peanut agglutinin from Arachis hypogea cotyledon-derived suspension cultures, DB58 lectin from Dolichos biflorus cell suspension cultures, and Aralin lectin from Aralia elata callus cultures [64-68]. Rorrer et al. [69,70] demonstrated that marine algal cell culture can be used to manufacture various bioactive metabolites; however, there are limited studies on the production of lectins specifically.

Chen [71] established a suspension culture from Porphyra linearis protoplasts in 1989, making it one of the earliest reports of successful cell suspension culture of marine algae. This culture was maintained and cultured for four years without the formation of organized thalli [71]. Additionally, Rorrer [72] also reported that, in order to cultivate marine alga suspension successfully, culture conditions must be similar to those of the parent seaweeds, as demonstrated in the developed phototropic suspension cultures of the brown alga Laminaria Saccharina [72]. Isolation and culture of microscopic gametophytes, initiation and culture of callus-like tissue, partial regeneration of freely suspended microplantlets from callus-like tissue, and isolation and suspension culture of apical meristems from marine algae are among the techniques used [72]. Suspension culture of Agardhiella subulata, a macrophytic red alga, has been reported by Rorrer [72] using two culture steps: (1) undifferentiated filament clumps and (2) micro-plantlets from partial regeneration of the filament clumps. Both cultures were suspended freely in liquid media and can be maintained indefinitely with periodic subcultures. Micro-plantlet suspension cultures were not only used to establish new cultures, but they were also shown to selectively produce bioactive metabolites in Ochtodes secundiramae, a macrophytic red alga [73,74].

Schnell et al. [64] described the process of preparing lectin by culturing Dolichus biflorus callus in liquid media as a cell suspension culture. The callus tissue grew rapidly, with cell mass increasing by more than 14-fold in just one week. However, after being transferred to new media, the growth decelerated for three days before entering an exponential growth phase for six days before beginning to decline [64]. When compared to lectin production in plants tissue, the amount of lectin production in the plant suspension cultures follows a similar pattern [64]. In marine algae, although the cellular organization of red and brown algae differs, their callus exhibits similar morphology. Their filamentous callus is rigid and was observed to regenerate rapidly into full plants when transferred to liquid media, limiting the range of applications that cell suspension cultures offer in comparison to higher plant applications [63]. While conventional algal lectin extraction methods generally produce higher yields, they do not ensure long-term sustainability of the marine algae because the biomass degrades after a single extraction. Ideally, the production of lectins using a non-destructive extracellular extraction method from cell suspension media would result in more stable and consistent yields. Additionally, Chen et al. [71] predicted that large-scale cell suspension cultures could be developed to produce specific fine chemicals. Rorrer et al. [70] confirmed the finding by successfully developing a 
photolithothropic suspension culture system of marine algae and biosynthesizing three bioactive hydroxy fatty acids with it. Recently, Polzin and Rorrer [73] successfully cultured Ochtodes secundiramea for the production of $\beta$-myrcene using micro-plantlet suspension cultures. Reports of higher plants producing lectin in plant cell suspension cultures also hint at the possibility of algal lectin production in suspension cultures [64-68]. Overall, these findings show that lectin can be extracted from marine algae cell suspension culture if the production process is followed correctly.

\section{Recent Advances in Algal Lectin Isolation}

The protein digestibility of marine algae in their raw and unprocessed forms is poor. Therefore, much emphasis has been placed on developing improved methods for algal protein extraction to increase bioavailability [8]. Some of the methods developed by researchers to obtain active compounds from algal biomass without losing their bioactivity are microwave-assisted extraction (MAE), ultrasound-assisted extraction (UAE), enzyme-assisted extraction (EAE), supercritical fluid extraction (SFE), and subcritical water extraction (SWE) $[14,75,76]$. However, until recently, when Djabayan-Djibeyan et al. [13] developed a novel cold steeping infusion (CSI) technique based on their observations of lectin release from marine algae into their extracellular environment, lectin extraction from marine algae remained limited.

Microwave-assisted extraction (MAE) is a type of microwave heating caused by dipole rotation of a polar solvent and ionic conduction of dissolved ions, which causes cell rupture and compound release into the solvent [77]. MAE reduces solvent consumption and shortens extraction time, making it an efficient technique [58,78]. Ultrasound-assisted extraction (UAE) is typically performed with an ultrasonic bath and ultrasonic probe, in which a solid matrix is dispersed into a solvent in an ultrasonic bath in a stainless steel tank connected to the transducer. UAE improves the extraction process by reducing particle size and increasing mass transfer through the cell wall, which is accomplished through cavitation-induced bubble collapse [79]. It has also been reported that ultrasound pre-treatment increased the protein extraction yield of Ascophyllum nodosum by $27-540 \%$ and reduced the processing time by $50 \mathrm{~min}$ [60]. Meanwhile, enzyme-assisted extraction (EAE) uses enzymes to improve compound extraction in their native form [10], where the hydrolytic actions of enzymes are used to break down the cell walls and cuticles of marine algae. The breakdown is required because the cell walls and cuticles are made up of chemically complex and heterogenous biomolecules that must be broken down to extract bioactive compounds from the environment $[10,80]$. In supercritical fluid extraction (SFE), a supercritical fluid is a fluid with temperatures and pressures above its critical limit. The density of liquid in this state is similar to that of liquid, while its viscosity is similar to that of gas, and it has intermediate diffusivity between those of gas and liquid. Therefore, supercritical fluids possess better transport properties than liquids and allow for the extraction of bioactive compounds without degradation or loss of volatility $[80,81]$. Subcritical water extraction (SWE) is typically performed at high temperatures and pressures ranging from $50-200{ }^{\circ} \mathrm{C}$ and 50-300 psi for a short period of time with a small amount of solvent [82]. The high pressure causes the solvents to rise above their boiling point, and the increased temperature speeds up the extraction by increasing solubility and mass transfer rate [80,82]. Table 3 lists the various extraction methods used to extract specific compounds in marine algae. Although there has been no specific report on lectin isolation using these methods, the high rate and yield of seaweed protein extraction allows for possible lectin isolation from the crude protein extract. Following that, additional optimization and purification may be required to ensure successful lectin isolation using these assisted methods. 
Table 3. The assisted extraction methods for marine algae and their extracted compounds.

\begin{tabular}{|c|c|c|c|}
\hline Marine Alga Species & Extraction Method & Isolated Compounds & References \\
\hline Ascophyllym nodosum & $\begin{array}{l}\text { Microwave-assisted } \\
\text { extraction, } \\
\text { ultrasound-assisted } \\
\text { extraction }\end{array}$ & $\begin{array}{l}\text { Fucose-sulfated } \\
\text { polysaccharides }\end{array}$ & [9] \\
\hline $\begin{array}{l}\text { Sargassum aquifolium, } \\
\text { Sargassum ilicifolium, } \\
\text { Sargassum polycystum }\end{array}$ & $\begin{array}{l}\text { Enzyme-assisted } \\
\text { extraction }\end{array}$ & Phenolic compound & [11] \\
\hline Fucus vesiculosus & $\begin{array}{c}\text { Microwave-assisted } \\
\text { extraction }\end{array}$ & $\begin{array}{l}\text { Phlorotannins } \\
\text { Polysaccharides }\end{array}$ & [12] \\
\hline $\begin{array}{l}\text { Ascophyllum nodosum, } \\
\text { Laminaria japonica, } \\
\text { Lessonia trabeculate, } \\
\text { Lessonia nigrescens }\end{array}$ & $\begin{array}{c}\text { Microwave-assisted } \\
\text { extraction }\end{array}$ & Phenolic compounds & [77] \\
\hline Solieria chordalis & $\begin{array}{c}\text { Microwave-assisted } \\
\text { extraction }\end{array}$ & Carrageenan & [83] \\
\hline Ulva pertusa & $\begin{array}{c}\text { Microwave-assisted } \\
\text { extraction }\end{array}$ & Polysaccharides & [84] \\
\hline Padina pavonica & $\begin{array}{l}\text { Pressurized liquid } \\
\text { extraction, } \\
\text { Microwave-assisted } \\
\text { extraction }\end{array}$ & Water extract & [85] \\
\hline Pelvetia canaliculate & $\begin{array}{c}\text { Ultrasound-assisted } \\
\text { extraction }\end{array}$ & Antioxidants & [86] \\
\hline $\begin{array}{l}\text { Nizamuddinia } \\
\text { zanardinii }\end{array}$ & $\begin{array}{c}\text { Ultrasound-assisted } \\
\text { extraction }\end{array}$ & Fucoidans & [87] \\
\hline Undaria pinnatifida & $\begin{array}{c}\text { Enzyme-assisted } \\
\text { extraction }\end{array}$ & Fucoxanthin & [88] \\
\hline $\begin{array}{c}\text { Haematococcus } \\
\text { pluvialis }\end{array}$ & $\begin{array}{l}\text { Supercritical fluid } \\
\text { extraction }\end{array}$ & Astaxanthin & [89] \\
\hline Sargassum muticum & $\begin{array}{c}\text { Supercritical fluid } \\
\text { extraction }\end{array}$ & Polyphenols & [90] \\
\hline $\begin{array}{c}\text { Polysiphonia nigrescens, } \\
\text { Ulva clathrata, } \\
\text { Cladophora sp. }\end{array}$ & $\begin{array}{l}\text { Supercritical fluid } \\
\text { extraction with } \mathrm{CO}_{2}\end{array}$ & $\begin{array}{c}\text { Auxins } \\
\text { Cytokinins } \\
\text { Polyphenols } \\
\text { Microelements } \\
\text { Macroelements }\end{array}$ & [91] \\
\hline Saccharina japonica & $\begin{array}{l}\text { Subcritical water } \\
\text { extraction }\end{array}$ & Fucoidan & {$[92]$} \\
\hline $\begin{array}{c}\text { Ascophyllum nodosum, } \\
\text { Pelvetia canaliculata, } \\
\text { Fucus spiralis, } \\
\text { Ulva intestinalis }\end{array}$ & $\begin{array}{l}\text { Subcritical water } \\
\text { extraction }\end{array}$ & Polyphenols & [93] \\
\hline
\end{tabular}

Several studies have shown that marine algae contain lectins capable of producing distinct biological activities such as bacterial, yeasts, and algal aggregation [44], implying that lectins can act as a protection against potentially harmful microorganisms [44,94,95]. Studies have also discovered that marine algae release lectins and lectin inhibitors, such as the monosaccharide $\mathrm{N}$-acetyl-D-galactosamine in some algae, into their extracellular environment via a cellular transport system, indicating the presence of lectin compounds in the surrounding media and potentially allowing for lectin recovery from the media $[95,96]$. Djabayan-Djibeyan et al. [13] developed the cold steeping infusion (CSI) technique in 
response to their prior study in 2010 [95], which investigated the in vivo lectin release from Ulva fasciata. The CSI technique is a novel method for recovering lectins from an algal culture in media without damaging the producing tissues. Even after being activated from dormancy, marine algae can release extracellular bioactive compounds such as lectins, which can then be continuously retrieved from buffer solutions, and the producing algae can be used for subsequent culture cycles.

The CSI technique allows the marine algae to return to its metabolic state after being stored for an extended period of time by immersing it in a simple buffer under an artificial light source. Marine algae could be immersed in a phosphate buffered saline (PBS) solution for $48 \mathrm{~h}$ before being collected and treated with solid ammonium sulfate to achieve an $85 \%$ sulfate saturation. The crude protein would be released into the PBS solution before being purified further using affinity chromatography [13]. The CSI technique demonstrated similar efficiency in lectin production from the green alga Caulerpa serrulate with conventional liquid nitrogen grinding (GLN) method, yielding approximately $407.2 \mathrm{mg}$ of total soluble protein and GLN method yielding $308.4 \mathrm{mg}$ of total soluble protein. After purification with a GalNAc-sepharose affinity chromatography column, the protein attached to the column for the GLN and CSI methods was $4.7 \mathrm{mg}$ and $4.2 \mathrm{mg}$, respectively. Further analysis using SDS-PAGE and size exclusion chromatography also revealed that lectin isolated using both techniques had similar molecular size and molecular weight. This result showed that the CSI technique does not disrupt lectin structure because the lectin released into the buffer exhibited characteristics comparable to lectin extracted from marine algal tissues.

\section{Non-Destructive Extracellular Lectin Production in Bioreactors}

Seaweed bioprocess engineering is one of the most cutting-edge developments in seaweed biotechnology. Previous research has revealed that seaweeds can be produced and recovered directly from cells and cells aggregates in photobioreactors [97]. Transferring a biosynthetic process from a shake flask to a bioreactor may appear to be simple and straightforward, but there are a few disadvantages in the case of plant cell cultures. The issues may arise as a result of the biosynthesis of chemicals being dependent on several interconnected factors, including compound sensitivity to shear forces, tissue growth rate, plant cell aggregation and wall-associated growth, and cell flotations [73,97-99].

The recently developed CSI technique has the potential to be widely used, because it does not require the establishment of cell suspension culture prior to lectin production [13]. As illustrated in Figure 1, this method eliminates the need for suspension culture establishment and a lengthy culture cycle to achieve cell stability for continuous culture.

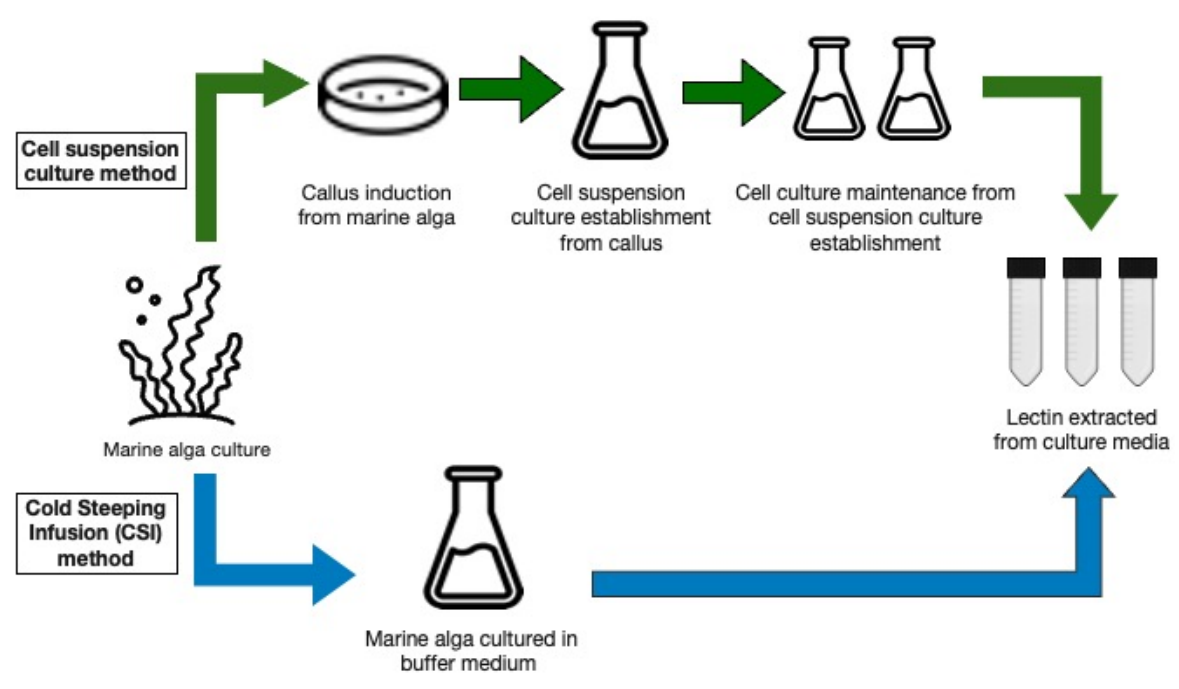

Figure 1. A basic illustration of cell suspension culture and cold steeping infusion (CSI) method for producing lectin in culture media. 
According to Rao and Ravishankar [100], in vitro cell culture has the advantages of producing bioactive compounds with a defined system and a short culture time, as well as a constant supply of target metabolites. In vitro cultures are often protected from diseases and seasonal variations [101]. On the other hand, the CSI method enables marine algae to revert to a metabolically active state after prolonged storage in buffer solution without causing tissue damage. As a result, this technique is ideal for continuous lectin production since it does not destroy existing algae and allows them to remain as a whole living plant.

The use of a bioreactor to produce plant bioactive compounds allows for better monitoring of the physical and cultural environments, and easier optimization and observation. Yields would be more reproducible and bioactive compound concentrations would be more accessible under controlled growth conditions [72]. Bioprocess technology for marine algae involves the production of cell and tissue cultures, the design of photobioreactors, and the identification of strategies for eliciting secondary metabolite biosynthesis [1]. The growth of marine algae in the bioreactor needs to be optimized to ensure a high yield of lectin production. Marine algae growth and development are influenced by light, temperature, nutrients, salinity, and water movement in the culture media [102].

According to Rorrer and Cheney [1], the airlift photobioreactor shows promising results in terms of mixing, aeration and gas exchange, light transfer, and being less damaging to algal tissues. To integrate the photobioreactor into the CSI system, it could be connected to a chiller and have a jacketed vessel, or it could be kept in a cold room to keep the buffer solution at $4{ }^{\circ} \mathrm{C}$. Maintaining the $\mathrm{pH}$ of the buffer solution is also crucial because $\mathrm{pH}$ fluctuations can interfere with lectin activity, such as hemagglutination. Additionally, the most important prerequisites for commercial lectin mass production are the selection of a starting material with high lectin production capability and the use of a simple purification technique [3]. Pterocladiella capillacea and Spirogyra spp. lectins were successfully purified using a cross-linked guar-gum affinity column [103,104], while Caulerpa serraluta lectins were purified using a Sepharose-GalNac affinity column [13], S. filiformis lectins were purified using a DEAE-sephacel ion exchange chromatography column [32], and Kappaphycus alvarezii lectins were purified using an ion exchange chromatography [84]. According to Rorrer and Cheney [1], photobioreactor configuration is related to several effects in culture, including mixing and biomass suspension, aeration and gas exchange, light transfer, and shear damage potential. These factors are critical because they influence the process and end products of the culture. The available photobioreactors include the bubble column photobioreactor, the airlift photobioreactor, the stirred tank photobioreactor (externally illuminated) and the tubular recycle photobioreactor (helical array). Among all photobioreactors, the stirred tank bioreactor demonstrated excellent mixing and biomass suspension, and good to excellent aeration and gas exchange of the culture. However, its light transfer is poor, posing a high risk of shear damage to the culture. On the other hand, an airlift photobioreactor provides very good mixing and biomass suspension quality, as well as better light transfer and a low potential for shear damage in the culture [1]. This photobioreactor would be an excellent candidate for the CSI method to be combined with because it is less likely to damage marine algae in the culture and provides good light transfer to maximize algal productivity.

\section{Prospects for Algal Lectin Production}

Algal lectin's potential has become more apparent over time as more research has been conducted to demonstrate its benefits. Apart from its antiviral properties, algal lectin has also shown promising results in therapeutic applications. These applications include cancer diagnosis and prognosis, pathological markers of disease, cell-cell communication, and glycan profiling due to its sugar binding specificity for glycoconjugates. As more lectins are extracted and research on the isolated lectins is conducted, it has been discovered that lectin production from marine algae can be improved for maximum benefit.

Significant research on lectin extraction has been conducted in recent decades, and several methods have clearly demonstrated higher lectin yields. Generally, the mechanical 
method was used, followed by treatment with buffer media and protein precipitation (Table 2). The advancement of various assisted-extraction methods such as MAE, UAE, SFE, and EAE has resulted in a significant increase in the yield of protein extracted while saving more energy and time. Nevertheless, despite the potential improvements made, ongoing research is required to produce lectin on a larger scale and in a more sustainable manner.

Lectin production in culture media would save time and pose fewer health risks to humans and the environment because no harmful solvents would be used in the extraction process. Isolation of lectin from culture media enables the marine algae to be re-cultured and restored to its metabolic functions, preventing the marine algae from being replenished after a single extraction. This feature is highly beneficial to sustainability, because the biomass can be reused for lectin production while also reducing competition with the food industry, where many algae species are primarily grown for food. Therefore, it is crucial to continue the research done by Djabayan-Djibeyan et al. [13,95]. Moreover, additional research in bioreactor systems for marine algal metabolites production will add more insight to the previous discovery [1,72], as many species of marine algae show potential for large-scale cultivation. Large-scale algal lectin production will greatly expand opportunities for algal lectin research, such as antiviral activity against HIV and various influenza viruses. This effort may result in a greater number of therapeutic agents being developed against new viruses that may emerge in the future, as new vaccines may not be readily available at the time.

Inadequate information regarding large-scale cultivation and production of lectin has prevented researchers from conducting commercial trials, as a significantly large amount of marine algae would be needed to run the trial, as opposed to extracting lectin using conventional method, which only uses a smaller amount of marine algae. The large amount of marine algae required in commercial lectin production makes it less appealing, and it is necessary to develop successful culturing technology for targeted lectin production to be more feasible and economically viable. Bioproducts derived from marine algae vary according to species and affected by physical and environmental factors. These factors include nutrient availability, temperature, $\mathrm{pH}$, salinity, light intensity, and carbon dioxide level, as well as the stirring and mixing conditions of the photobioreactor. These factors are vital and must be optimized before conducting a commercial trial. Additionally, commercial lectin production necessitates a fast-growing culture to ensure a higher yield of lectin, such as the supply of some strongly limiting substances or the use of specific growth-promoting bacteria to enhance the growth rate of marine algae.

As interest in marine algae biotechnology grows, more relevant techniques and methods are being developed, and extensive research is required to develop the non-disruptive lectin production method into one of the commercially viable methods. Despite no satisfactory progress in large-scale production of marine algal lectin having yet been reported, the outlook for the near future is optimistic.

\section{Summary}

Marine algae are a rich source of novel lectins. As previously reported, these novel lectins appear to demonstrate antiviral, anticancer, and anti-inflammatory properties, implying a broad range of therapeutic applications. The advancement of lectin extraction techniques from marine algae also aids in the isolation of a greater number of novel lectins. Though these techniques show promising results in lectin extraction at the laboratory scale, more research is needed before they can be applied on a larger scale, such as in a bioreactor or in a commercial setting. Phototrophic suspension culture and micro-plantlet suspension may differ in bioreactor due to their sensitivity to shear force, growth rate and aggregation tendencies. The recently developed CSI technique may be able to overcome these challenges in continuous lectin production from marine algae without causing tissues disruption. This breakthrough is due to the fact that no preceding cell suspension culture is required, and the culture relies on the release of lectin into the culture media by marine algae to ensure continuous recovery. The development of the CSI method is important to reduce the 
competition of marine algae culture dependence with the food and feed industries. The CSI technology may be able to fulfil the demand for bioactive chemicals derived from marine algae, such as lectin production for future medical and biotechnological applications.

Author Contributions: Conceptualization, M.M., P.L.T. and W.T.L.Y.; methodology, I.M.M., K.F.R. and W.T.L.Y.; software, I.M.M., M.M. and K.F.R.; validation, P.L.T. and W.T.L.Y.; formal analysis, I.M.M. and M.M.; investigation, I.M.M. and W.T.L.Y.; resources, P.L.T., K.F.R. and W.T.L.Y.; data curation, I.M.M. and M.M.; writing—original draft preparation, I.M.M.; writing—review and editing, M.M., P.L.T., K.F.R. and W.T.L.Y.; visualization, I.M.M. and M.M.; supervision, M.M., P.L.T. and W.T.L.Y.; project administration, W.T.L.Y.; funding acquisition, W.T.L.Y. All authors have read and agreed to the published version of the manuscript.

Funding: This review was funded by the Universiti Malaysia Sabah under a Skim Dana Khas (SDK0199-2020) entitled "Production of KappaLec@(C) with therapeutic potential against coronavirus".

Institutional Review Board Statement: Not applicable.

Informed Consent Statement: Not applicable.

Data Availability Statement: Not applicable.

Acknowledgments: The authors would like to thank the Universiti Malaysia Sabah for supporting the project financially and administratively.

Conflicts of Interest: The authors declare no conflict of interest.

\section{References}

1. Rorrer, G.L.; Cheney, D.P. Bioprocess Engineering of Cell and Tissue Cultures for Marine Seaweeds. Aquac. Eng. 2004, 32, 11-41. [CrossRef]

2. Pliego-Cortés, H.; Wijesekara, I.; Lang, M.; Bourgougnon, N.; Bedoux, G. Current Knowledge and Challenges in Extraction, Characterization and Bioactivity of Seaweed Protein and Seaweed-Derived Proteins. Adv. Bot. Res. 2020, 95, $289-326$.

3. Lam, S.; Ng, T. Lectins: Production and Practical Applications. Appl. Microbiol. Biotechnol. 2011, 89, 45-55. [CrossRef] [PubMed]

4. Tsaneva, M.; Van Damme, E.J.M. 130 Years of Plant Lectin Research. Glycoconj. J. 2020, 37, 533-551. [CrossRef]

5. Boyd, W.C.; Almodovar, L.R.; Boyd, L.G. Agglutinins in Marine Algae for Human Erythrocytes. Transfusion 1966, 6, 82-83. [CrossRef]

6. Molchanova, V.; Chernikov, O.; Chikalovets, I.; Lukyanov, P. Purification and Partial Characterization of the Lectin from the Marine Red Alga Tichocarpus Crinitus. Rupr. Bot. Mar. 2010, 53, 69-78. [CrossRef]

7. Stengel, D.B.; Connan, S.; Popper, Z.A. Algal Chemodiversity and Bioactivity: Sources of Natural Variability and Implications for Commercial Application. Biotechnol. Adv. 2011, 29, 483-501. [CrossRef]

8. Bleakley, S.; Hayes, M. Algal Proteins: Extraction, Application, and Challenges Concerning Production. Foods 2017, 6, 33. [CrossRef]

9. Garcia-Vaquero, M.; Ummat, V.; Tiwari, B.; Rajauria, G. Exploring Ultrasound, Microwave and Ultrasound-Microwave Assisted Extraction Technologies to Increase the Extraction of Bioactive Compounds and Antioxidants from Brown Macroalgae. Mar. Drugs 2020, 18, 172. [CrossRef]

10. Terme, N.; Hardouin, K.; Cortès, H.P.; Peñuela, A.; Freile-Pelegrín, Y.; Robledo, D.; Bedoux, G.; Bourgougnon, N. Chapter 10-Emerging Seaweed Extraction Techniques: Enzyme-Assisted Extraction a Key Step of Seaweed Biorefinery ? In Sustainable Seaweed Technologies; Torres, M.D., Kraan, S., Dominguez, H., Eds.; Elsevier: Amsterdam, The Netherlands, 2020 ; pp. $225-256$.

11. Puspita, M.; Deniel, M.; Widowati, I.; Radjasa, O.K.; Douzenel, P.; Bedoux, G.; Bourgougnon, N. Antioxidant and Antibacterial Activity of Solid-Liquid and Enzyme-Assisted Extraction of Phenolic Compound from Three Species of Tropical Sargassum. IOP Conf. Ser. Earth Environ. Sci. 2017, 55, 012057. [CrossRef]

12. Amarante, S.J.; Catarino, M.D.; Marçal, C.; Silva, A.M.S.; Ferreira, R.; Cardoso, S.M. Microwave-Assisted Extraction of Phlorotannins from Fucus vesiculosus. Mar. Drugs 2020, 18, 559. [CrossRef] [PubMed]

13. Djabayan-Djibeyan, P.; Carpenter, B.; Medina-Ramírez, G.; Andueza-Leal, F.; León-Leal, A.; Djabayan-Russo, A.; Jaramillo-Abril, D.; Valarezo-García, C.; Araujo-Baptista, L. Cold Steeping Infusion, a Novel Lectin Extraction Technique for the Isolation, Purification and Partial Characterization of Lectins from the Green Venezuelan Marine Alga Caulerpa serrulata. Nat. Prod. Commun. 2018, 13, 1715-1719. [CrossRef]

14. Michalak, I.; Chojnacka, K. Algae as Production Systems of Bioactive Compounds. Eng. Life Sci. 2014, 15, 160-176. [CrossRef]

15. Øverland, M.; Mydland, L.T.; Skrede, A. Marine Macroalgae as Sources of Protein and Bioactive Compounds in Feed for Monogastric Animals. J. Sci. Food Agric. 2019, 99, 13-24. [CrossRef]

16. Lupatini, A.L.; Colla, L.M.; Canan, C.; Colla, E. Potential Application of Microalga Spirulina platensis as a Protein Source. J. Sci. Food Agric. 2017, 97, 724-732. [CrossRef] [PubMed] 
17. Pereira, L.; Silva, P. A Concise Review of the Red Macroalgae Chondracanthus teedei (Mertens Ex Roth) Kützing and Chondracanthus teedei var. lusitanicus (J.E. De Mesquita Rodrigues) Bárbara \& Cremades. J. Appl. Phycol. 2021, 33, 111-131.

18. Mæhre, H.K.; Malde, M.K.; Eilertsen, K.; Elvevoll, E.O. Characterization of Protein, Lipid and Mineral Contents in Common Norwegian Seaweeds and Evaluation of Their Potential as Food and Feed. J. Sci. Food Agric. 2014, 94, 3281-3290. [CrossRef]

19. Marsham, S.; Scott, G.W.; Tobin, M.L. Comparison of Nutritive Chemistry of a Range of Temperate Seaweeds. Food Chem. 2007, 100, 1331-1336. [CrossRef]

20. Fleurence, J.; Le Coeur, C.; Mabeau, S.; Maurice, M.; Landrein, A. Comparison of Different Extractive Procedures for Proteins from the Edible Seaweeds Ulva rigida and Ulva rotundata. J. Appl. Phycol. 1995, 7, 577-582. [CrossRef]

21. Masarin, F.; Cedeno, F.R.P.; Chavez, E.G.S.; de Oliveira, L.E.; Gelli, V.C.; Monti, R. Chemical Analysis and Biorefinery of Red Algae Kappaphycus alvarezii for Efficient Production of Glucose from Residue of Carrageenan Extraction Process. Biotechnol. Biofuels 2016, 9, 122. [CrossRef]

22. Admassu, H.; Abera, T.; Abraha, B.; Yang, R.; Zhao, W. Proximate, Mineral and Amino Acid Composition of Dried Laver (Porphyra Spp.) Seaweed. J. Acad. Ind. Res. 2018, 6, 149.

23. Barbarino, E.; Lourenço, S.O. An Evaluation of Methods for Extraction and Quantification of Protein from Marine Macro- and Microalgae. J. Appl. Phycol. 2005, 17, 447-460. [CrossRef]

24. Praseptiangga, D. Algal Lectins and Their Potential Uses. Squalen Bull. Mar. Fish. Postharvest Biotechnol. 2015, 10, 89-98. [CrossRef]

25. Brooks, S.; Dwek, M.; Schumacher, U. Functional and Molecular Glycobiology; Garland Science: New York, NY, USA, 2002.

26. Ludwig, A.-K.; Kaltner, H.; Kopitz, J.; Gabius, H.-J. Lectinology 4.0: Altering Modular (Ga) Lectin Display for Functional Analysis and Biomedical Applications. Biochim. Biophys. Acta. Gen. Subj. 2019, 1863, 935-940. [CrossRef] [PubMed]

27. Silva, M.L.S. Chapter One-Lectin Biosensors in Cancer Glycan Biomarker Detection. Adv. Clin. Chem. 2019, 93, 1-61.

28. Stillmark, H. Über Ricin ein Giftiges Ferment aus den Samen von Ricinus communis L. und Einigen Anderen Euphorbiaceen. Inaugural Dissertation, University of Dorpat, Dorpat, Estonia, 1888.

29. Singh, R.S.; Thakur, S.R.; Bansa, P. Algal Lectins as Promising Biomolecules for Biomedical Research. Crit. Rev. Microbiol. 2015, 41, 77-88. [CrossRef]

30. Teixeira, E.H.; Arruda, F.V.S.; do Nascimento, K.S.; Carneiro, V.A.; Nagano, C.S.; da Silva, B.R.; Sampaio, A.H.; Cavada, B.S. Biological Applications of Plants and Algae Lectins: An Overview. In Carbohydrates-Comprehensive Studies on Glycobiology and Glycotechnology; IntechOpen: London, UK, 2012.

31. Catanzaro, E.; Calcabrini, C.; Bishayee, A.; Fimognari, C. Antitumor Potential of Marine and Freshwater Lectins. Mar. Drugs 2020, 18, 11. [CrossRef]

32. Chaves, R.P.; da Silva, S.R.; Neto, L.G.N.; Carneiro, R.F.; da Silva, A.L.C.; Sampaio, A.H.; de Sousa, B.L.; Cabral, M.G.; Videira, P.A.; Teixeira, E.H.; et al. Structural Characterization of Two Isolectins from the Marine Red Alga Solieria filiformis (Kützing) P.W. Gabrielson and Their Anticancer Effect on MCF-7 Breast Cancer Cells. Int. J. Biol. Macromol. 2018, 107, 1320-1329. [CrossRef]

33. Sato, Y.; Morimoto, K.; Hirayama, M.; Hori, K. High Mannose-Specific Lectin (KAA-2) from the Red Alga Kappaphycus alvarezii Potently Inhibits Influenza Virus Infection in a Strain-Independent Manner. Biochem. Biophys. Res. Commun. 2011, 405, 291-296. [CrossRef]

34. Sugahara, T.; Ohama, Y.; Fukuda, A.; Hayashi, M.; Kawakubo, A.; Kato, K. The Cytotoxic Effect of Eucheuma serra Agglutinin (ESA) on Cancer Cells and Its Application to Molecular Probe for Drug Delivery System Using Lipid Vesicles. Cytotechnology 2001, 36, 93-99. [CrossRef]

35. Takebe, Y.; Saucedo, C.J.; Lund, G.; Uenishi, R.; Hase, S.; Tsuchiura, T.; Kneteman, N.; Ramessar, K.; Tyrrell, D.L.J.; Shirakura, M. Antiviral Lectins from Red and Blue-Green Algae Show Potent in Vitro and in Vivo Activity against Hepatitis C Virus. PLoS ONE 2013, 8, e64449. [CrossRef] [PubMed]

36. Mitchell, C.A.; Ramessar, K.; O’Keefe, B.R. Antiviral Lectins: Selective Inhibitors of Viral Entry. Antiviral Res. 2017, 142, 37-54. [CrossRef] [PubMed]

37. Mori, T.; O'Keefe, B.R.; Sowder, R.C.; Bringans, S.; Gardella, R.; Berg, S.; Cochran, P.; Turpin, J.A.; Buckheit, R.W.; McMahon, J.B. Isolation and Characterization of Griffithsin, a Novel HIV-Inactivating Protein from the Red Alga Griffithsia sp. J. Biol. Chem. 2005, 280, 9345-9353. [CrossRef] [PubMed]

38. Mu, J.; Hirayama, M.; Sato, Y.; Morimoto, K.; Hori, K. A Novel High-Mannose Specific Lectin from the Green Alga Halimeda renschii Exhibits a Potent Anti-Influenza Virus Activity through High-Affinity Binding to the Viral Hemagglutinin. Mar. Drugs 2017, 15, 255. [CrossRef] [PubMed]

39. Hori, K.; Matsuda, H.; Miyazawa, K.; Ito, K. A Mitogenic Agglutinin from the Red Alga Carpopeltis flabellata. Phytochemistry 1987, 26, 1335-1338. [CrossRef]

40. Barre, A.; Van Damme, E.J.; Simplicien, M.; Le Poder, S.; Klonjkowski, B.; Benoist, H.; Peyrade, D.; Rougé, P. Man-Specific Lectins from Plants, Fungi, Algae and Cyanobacteria, as Potential Blockers for SARS-CoV, MERS-CoV and SARS-CoV-2 (COVID-19) Coronaviruses: Biomedical Perspectives. Cells 2021, 10, 1619. [CrossRef]

41. Alam, M.; Parra-Saldivar, R.; Bilal, M.; Afroze, C.A.; Ahmed, M.; Iqbal, H.; Xu, J. Algae-Derived Bioactive Molecules for the Potential Treatment of Sars-Cov-2. Molecules 2021, 26, 2134. [CrossRef]

42. Thompson, A.J.; Cao, L.; Ma, Y.; Wang, X.; Diedrich, J.K.; Kikuchi, C.; Willis, S.; Worth, C.; McBride, R.; Yates, J.R., III. Human Influenza Virus Hemagglutinins Contain Conserved Oligomannose N-Linked Glycans Allowing Potent Neutralization by Lectins. Cell Host Microbe 2020, 27, 725-735. [CrossRef] 
43. Hayashi, K.; Walde, P.; Miyazaki, T.; Sakayama, K.; Nakamura, A.; Kameda, K.; Masuda, S.; Umakoshi, H.; Kato, K. Active Targeting to Osteosarcoma Cells and Apoptotic Cell Death Induction by the Novel Lectin Eucheuma serra Agglutinin Isolated from a Marine Red Alga. J. Drug Deliv. 2012, 2012, 842785. [CrossRef]

44. Liao, W.; Lin, J.; Shieh, W.; Jeng, W.; Huang, R. Antibiotic Activity of Lectins from Marine Algae against Marine Vibrios. J. Ind. Microbiol. Biotechnol. 2003, 30, 433-439. [CrossRef]

45. Monteiro Abreu, T.; Maria Castelo Melo Silva, L.; Sousa Oliveira Vanderlei, E.; Moutinho Lagos de Melo, C.; Rego Alves Pereira, V.; Maria Barros Benevides, N. Cytokine Production Induced by Marine Algae Lectins in BALB/c Mice Splenocytes. Protein Pept. Lett. 2012, 19, 975-981. [CrossRef] [PubMed]

46. Gondim, A.C.S.; da Silva, S.R.; Mathys, L.; Noppen, S.; Liekens, S.; Sampaio, A.H.; Nagano, C.S.; Rocha, C.R.C.; Nascimento, K.S.; Cavada, B.S.; et al. Potent Antiviral Activity of Carbohydrate-Specific Algal and Leguminous Lectins from the Brazilian Biodiversity. Med. Chem. Commun. 2019, 10, 390-398. [CrossRef] [PubMed]

47. Fukuda, Y.; Sugahara, T.; Ueno, M.; Fukuta, Y.; Ochi, Y.; Akiyama, K.; Miyazaki, T.; Masuda, S.; Kawakubo, A.; Kato, K. The Anti-Tumor Effect of Euchema serra Agglutinin on Colon Cancer Cells in Vitro and in Vivo. Anticancer Drugs 2006, 17, $943-947$. [CrossRef] [PubMed]

48. Mesquita, J.X.; de Brito, T.V.; Fontenelle, T.P.C.; Damasceno, R.O.S.; de Souza, M.H.L.P.; de Souza Lopes, J.L.; Beltramini, L.M.; Barbosa, A.L.R.; Freitas, A.L.P. Lectin from Red Algae Amansia multifida Lamouroux: Extraction, Characterization and Anti-Inflammatory Activity. Int. J. Biol. Macromol. 2021, 170, 532-539. [CrossRef] [PubMed]

49. Kawakubo, A.; Makino, H.; Ohnishi, J.; Hirohara, H.; Hori, K. Occurrence of Highly Yielded Lectins Homologous within the Genus Eucheuma. J. Appl. Phycol. 1999, 11, 149-156. [CrossRef]

50. Millet, J.K.; Séron, K.; Labitt, R.N.; Danneels, A.; Palmer, K.E.; Whittaker, G.R.; Dubuisson, J.; Belouzard, S. Middle East Respiratory Syndrome Coronavirus Infection is Inhibited by Griffithsin. Antivir. Res. 2016, 133, 1-8. [CrossRef]

51. O'Keefe, B.R.; Giomarelli, B.; Barnard, D.L.; Shenoy, S.R.; Chan, P.K.; McMahon, J.B.; Palmer, K.E.; Barnett, B.W.; Meyerholz, D.K.; Wohlford-Lenane, C.L. Broad-Spectrum in Vitro Activity and in Vivo Efficacy of the Antiviral Protein Griffithsin against Emerging Viruses of the Family Coronaviridae. J. Virol. 2010, 84, 2511-2521. [CrossRef]

52. Lee, C. Griffithsin, a Highly Potent Broad-Spectrum Antiviral Lectin from Red Algae: From Discovery to Clinical Application. Mar. Drugs 2019, 17, 567. [CrossRef]

53. Ishag, H.Z.A.; Li, C.; Wang, F.; Mao, X. Griffithsin Binds to the Glycosylated Proteins (E and prM) of Japanese Encephalitis Virus and Inhibit Its Infection. Virus Res. 2016, 215, 50-54. [CrossRef]

54. Nixon, B.; Stefanidou, M.; Mesquita, P.M.M.; Fakioglu, E.; Segarra, T.; Rohan, L.; Halford, W.; Palmer, K.E.; Herold, B.C. Griffithsin Protects Mice from Genital Herpes by Preventing Cell-to-Cell Spread. J. Virol. 2013, 87, 6257-6269. [CrossRef]

55. Barre, A.; Simplicien, M.; Benoist, H.; Van Damme, E.J.M.; Rougé, P. Mannose-Specific Lectins from Marine Algae: Diverse Structural Scaffolds Associated to Common Virucidal and Anti-Cancer Properties. Mar. Drugs 2019, 17, 440. [CrossRef] [PubMed]

56. Pinto, V.P.T.; Debray, H.; Dus, D.; Teixeira, E.H.; de Oliveira, T.M.; Carneiro, V.A.; Teixeira, A.H.; Filho, G.C.; Nagano, C.S.; Nascimento, K.S.; et al. Lectins from the Red Marine Algal Species Bryothamnion seaforthii and Bryothamnion triquetrum as Tools to Differentiate Human Colon Carcinoma Cells. Adv. Pharmacol. Pharm. Sci. 2009, 2009, 862162.

57. Calvete, J.J.; Costa, F.H.F.; Saker-Sampaio, S.; Murciano, M.P.M.; Nagano, C.S.; Cavada, B.S.; Grangeiro, T.B.; Ramos, M.V.; Bloch, C., Jr.; Silveira, S.B.; et al. The Amino Acid Sequence of the Agglutinin Isolated from the Red Marine Alga Bryothamnion triquetrum Defines a Novel Lectin Structure. Cell. Mol. Life Sci. 2000, 57, 343-350. [CrossRef] [PubMed]

58. Harnedy, P.A.; FitzGerald, R.J. Extraction of Protein from the Macroalga Palmaria palmata. LWT-Food. Sci. Technol. 2013, 51, 375-382. [CrossRef]

59. Gordalina, M.; Pinheiro, H.M.; Mateus, M.; da Fonseca, M.M.R.; Cesário, M.T. Macroalgae as Protein Sources—A Review on Protein Bioactivity, Extraction, Purification and Characterization. Appl. Sci. 2021, 11, 7969. [CrossRef]

60. Kadam, S.U.; Álvarez, C.; Tiwari, B.K.; O’Donnell, C.P. Extraction and Characterization of Protein from Irish Brown Seaweed Ascophyllum nodosum. Food Res. Int. 2017, 99, 1021-1027. [CrossRef]

61. Ganeva, V.; Galutzov, B.; Teissié, J. High Yield Electroextraction of Proteins from Yeast by a Flow Process. Anal. Biochem. 2003, 315, 77-84. [CrossRef]

62. Boisson, A.-M.; Gout, E.; Bligny, R.; Rivasseau, C. A Simple and Efficient Method for the Long-Term Preservation of Plant Cell Suspension Cultures. Plant Methods 2012, 8, 4. [CrossRef]

63. Reddy, C.; Jha, B.; Fujita, Y.; Ohno, M. Seaweed Micropropagation Techniques and Their Potentials: An Overview. J. Appl. Phycol. 2008, 20, 609-617. [CrossRef]

64. Schnell, D.J.; Hori, K.; Herrmann, S.M.; Gegg, C.V.; Etzler, M.E. Biosynthesis of DB58 Lectin in Cell Suspension Cultures of Dolichos biflorus. Arch. Biochem. Biophys. 1994, 310, 229-235. [CrossRef]

65. D'Silva, I.; Kumar Podder, S. Peanut Agglutinin from Callus and Cell Suspension Cultures of Arachis hypogaea L. Plant Cell Rep. 1994, 14, 50-54. [CrossRef] [PubMed]

66. Tomatsu, M.; Mujin, T.; Shibamoto, N.; Tashiro, F.; Ikuta, A. Production of Aralin, a Selective Cytotoxic Lectin against Human Transformed Cells, in Callus Culture of Aralia elata. Planta Med. 2004, 70, 469-471. [PubMed]

67. Ramakrishna, W.; Kumari, A.; Rahman, N.; Mandave, P. Anticancer Activities of Plant Secondary Metabolites: Rice Callus Suspension Culture as a New Paradigm. Rice Sci. 2021, 28, 13-30. [CrossRef] 
68. Macharoen, K.; Li, Q.; Márquez-Escobar, V.A.; Corbin, J.M.; Lebrilla, C.B.; Nandi, S.; McDonald, K.A. Effects of Kifunensine on Production and N-Glycosylation Modification of Butyrylcholinesterase in a Transgenic Rice Cell Culture Bioreactor. Int. J. Mol. Sci. 2020, 21, 6896. [CrossRef] [PubMed]

69. Rorrer, G.L.; Modrell, J.; Zhi, C.; Yoo, H.-D.; Nagle, D.N.; Gerwick, W.H. Bioreactor Seaweed Cell Culture for Production of Bioactive Oxylipins. J. Appl. Phycol. 1995, 7, 187-198. [CrossRef]

70. Rorrer, G.L.; Mullikin, R.; Huang, B.; Gerwick, W.H.; Maliakal, S.; Cheney, D.P. Production of Bioactive Metabolites by Cell and Tissue Cultures of Marine Macroalgae in Bioreactor Systems. In Plant Cell and Tissue Culture for the Production of Food Ingredients; Fu, T.-J., Singh, G., Curtis, W.R., Eds.; Springer: Boston, MA, USA, 1999; pp. 165-184.

71. Chen, L.C.M. Cell Suspension Culture from Porphyra linearis (Rhodophyta) a Multicellular Marine Red Alga. J. Appl. Phycol. 1989, 1, 153. [CrossRef]

72. Rorrer, G.L. Seaweeds: Cell and Tissue Suspension Cultures. In Encyclopedia of Cell Technology; American Cancer Society: Atlanta, GA, USA, 2003.

73. Polzin, J.; Rorrer, G.L. Selective Production of the Acyclic Monoterpene $\beta$-Myrcene by Microplantlet Suspension Cultures of the Macrophytic Marine Red Alga Ochtodes secundiramea under Nutrient Perfusion Cultivation with Bromide-Free Medium. Algal Res. 2018, 36, 159-166. [CrossRef]

74. Rorrer, G.L.; Tucker, M.P.; Cheney, D.P.; Maliakal, S. Bromoperoxidase Activity in Microplantlet Suspension Cultures of the Macrophytic Red Alga Ochtodes secundiramea. Biotechnol. Bioeng. 2001, 74, 389-395. [CrossRef]

75. Castro-Puyana, M.; Herrero, M.; Mendiola, J.; Ibáñez, E. Subcritical Water Extraction of Bioactive Components from Algae. In Functional Ingredients from Algae for Foods and Nutraceuticals; Woodhead Publishing: Shaston, UK, 2013; pp. 534-560.

76. Ibañez, E.; Herrero, M.; Mendiola, J.A.; Castro-Puyana, M. Extraction and Characterization of Bioactive Compounds with Health Benefits from Marine Resources: Macro and Micro Algae, Cyanobacteria and Invertebrates. In Marine Bioactive Compounds; Springer: Boston, MA, USA, 2012; pp. 55-98.

77. Yuan, Y.; Zhang, J.; Fan, J.; Clark, J.; Shen, P.; Li, Y.; Zhang, C. Microwave Assisted Extraction of Phenolic Compounds from Four Economic Brown Macroalgae Species and Evaluation of Their Antioxidant Activities and Inhibitory Effects on $\alpha$-Amylase, $\alpha$-Glucosidase, Pancreatic Lipase and Tyrosinase. Food Res. Int. 2018, 113, 288-297. [CrossRef]

78. Echave, J.; Fraga-Corral, M.; Garcia-Perez, P.; Popović-Djordjević, J.; Avdović, E.H.; Radulović, M.; Xiao, J.; Prieto, M.A.; SimalGandara, J. Seaweed Protein Hydrolysates and Bioactive Peptides: Extraction, Purification and Applications. Mar. Drugs 2021, 19, 500. [CrossRef]

79. Dang, T.T.; Van Vuong, Q.; Schreider, M.J.; Bowyer, M.C.; Van Altena, I.A.; Scarlett, C.J. Optimisation of Ultrasound-Assisted Extraction Conditions for Phenolic Content and Antioxidant Activities of the Alga Hormosira banksii Using Response Surface Methodology. J. Appl. Phycol. 2017, 29, 3161-3173. [CrossRef]

80. Kadam, S.U.; Tiwari, B.K.; O’Donnell, C.P. Application of Novel Extraction Technologies for Bioactives from Marine Algae. J. Agric. Food Chem. 2013, 61, 4667-4675. [CrossRef] [PubMed]

81. Messyasz, B.; Michalak, I.; Łęska, B.; Schroeder, G.; Górka, B.; Korzeniowska, K.; Lipok, J.; Wieczorek, P.; Rój, E.; Wilk, R.; et al. Valuable Natural Products from Marine and Freshwater Macroalgae Obtained from Supercritical Fluid Extracts. J. Appl. Phycol. 2018, 30, 591-603. [CrossRef] [PubMed]

82. Cikoš, A.-M.; Jokić, S.; Šubarić, D.; Jerković, I. Overview on the Application of Modern Methods for the Extraction of Bioactive Compounds from Marine Macroalgae. Mar. Drugs 2018, 16, 348. [CrossRef] [PubMed]

83. Boulho, R.; Marty, C.; Freile-Pelegrín, Y.; Robledo, D.; Bourgougnon, N.; Bedoux, G. Antiherpetic (HSV-1) Activity of Carrageenans from the Red Seaweed Solieria chordalis (Rhodophyta, Gigartinales) Extracted by Microwave-Assisted Extraction (MAE). J. Appl. Phycol. 2017, 29, 2219-2228. [CrossRef]

84. Le, B.; Golokhvast, K.S.; Yang, S.H.; Sun, S. Optimization of Microwave-Assisted Extraction of Polysaccharides from Ulva pertusa and Evaluation of Their Antioxidant Activity. Antioxidants 2019, 8, 129. [CrossRef]

85. Fayad, S.; Nehmé, R.; Tannoury, M.; Lesellier, E.; Pichon, C.; Morin, P. Macroalga Padina pavonica Water Extracts Obtained by Pressurized Liquid Extraction and Microwave-Assisted Extraction Inhibit Hyaluronidase Activity as Shown by Capillary Electrophoresis. J. Chromatogr. A 2017, 1497, 19-27. [CrossRef]

86. Sousa, G.; Trifunovska, M.; Antunes, M.; Miranda, I.; Moldão, M.; Alves, V.; Vidrih, R.; Lopes, P.A.; Aparicio, L.; Neves, M.; et al. Optimization of Ultrasound-Assisted Extraction of Bioactive Compounds from Pelvetia canaliculata to Sunflower Oil. Foods 2021, 10, 1732. [CrossRef]

87. Alboofetileh, M.; Rezaei, M.; Tabarsa, M.; Rittà, M.; Donalisio, M.; Mariatti, F.; You, S.; Lembo, D.; Cravotto, G. Effect of Different Non-Conventional Extraction Methods on the Antibacterial and Antiviral Activity of Fucoidans Extracted from Nizamuddinia zanardinii. Int. J. Biol. Macromol. 2019, 124, 131-137. [CrossRef]

88. Billakanti, J.M.; Catchpole, O.J.; Fenton, T.A.; Mitchell, K.A.; MacKenzie, A.D. Enzyme-Assisted Extraction of Fucoxanthin and Lipids Containing Polyunsaturated Fatty Acids from Undaria pinnatifida Using Dimethyl Ether and Ethanol. Process Biochem. 2013, 48, 1999-2008. [CrossRef]

89. Fujii, K. Process Integration of Supercritical Carbon Dioxide Extraction and Acid Treatment for Astaxanthin Extraction from a Vegetative Microalga. Food Bioprod. Process. 2012, 90, 762-766. [CrossRef] 
90. Anaëlle, T.; Serrano Leon, E.; Laurent, V.; Elena, I.; Mendiola, J.A.; Stéphane, C.; Nelly, K.; Stéphane, L.B.; Luc, M.; Valérie, S.-P. Green Improved Processes to Extract Bioactive Phenolic Compounds from Brown Macroalgae Using Sargassum muticum as Model. Talanta 2013, 104, 44-52. [CrossRef] [PubMed]

91. Michalak, I.; Górka, B.; Wieczorek, P.P.; Rój, E.; Lipok, J.; Łęska, B.; Messyasz, B.; Wilk, R.; Schroeder, G.; Dobrzyńska-Inger, A. Supercritical Fluid Extraction of Algae Enhances Levels of Biologically Active Compounds Promoting Plant Growth. Eur. J. Phycol. 2016, 51, 243-252. [CrossRef]

92. Saravana, P.S.; Cho, Y.-J.; Park, Y.-B.; Woo, H.-C.; Chun, B.-S. Structural, Antioxidant, and Emulsifying Activities of Fucoidan from Saccharina japonica Using Pressurized Liquid Extraction. Carbohydr. Polym. 2016, 153, 518-525. [CrossRef] [PubMed]

93. Tierney, M.S.; Smyth, T.J.; Hayes, M.; Soler-Vila, A.; Croft, A.K.; Brunton, N. Influence of Pressurised Liquid Extraction and Solid-Liquid Extraction Methods on the Phenolic Content and Antioxidant Activities of Irish Macroalgae. Int. J. Food Sci. Technol. 2013, 48, 860-869. [CrossRef]

94. Etzler, M. Distribution and Function of Plant Lectins. In The Lectins: Properties, Functions, and Applications in Biology and Medicine; Academic Press, Inc.: Cambridge, MA, USA, 1986; pp. 371-435.

95. Djabayan-Djibeyan, P.; Gibbs, R.; Carpenter, B. In Vivo Release of Lectins from the Green Alga Ulva fasciata. Nat. Prod. Commun. 2010, 5, 607-612. [CrossRef]

96. Huang, X.H.; Bomsel, M.; de Paillerets, C.; Weintraub, H.; Alfsen, A. Biochemical Characterization of Algal Coated Vesicles. Biochimie 1990, 72, 41-49. [CrossRef]

97. Georgiev, M.; Weber, J.; Maciuk, A. Bioprocessing of Plant Cell Cultures for Mass Production of Targeted Compounds. Appl. Microbiol. Biotechnol. 2009, 83, 809-823. [CrossRef]

98. Haas, C.; Weber, J.; Ludwig-Mueller, J.; Deponte, T.; Bley, T.; Georgiev, M. Flow Cytometry and Phytochemical Analysis of a Sunflower Cell Suspension Culture in a 5-L Bioreactor. Z. Naturforsch. C. J. Bio. Sci. 2008, 63, 699-705. [CrossRef]

99. Verpoorte, R.; Contin, A.; Memelink, J. Biotechnology for the Production of Plant Secondary Metabolites. Phytochem. Rev. 2002, 1, 13-25. [CrossRef]

100. Rao, R.; Ravishankar, G.A. Plant Cell Cultures: Chemical Factories of Secondary Metabolites. Biotechnol. Adv. 2002, 20, 101-153. [PubMed]

101. Castro, A.H.F.; da Silva Tavares, H.; Pereira, S.R.F.; Granjeiro, P.A.; da Silva, J.A.; Galdino, A.S. Production and Characterization of Lectin from Bauhinia holophylla (Fabaceae: Cercideae) Calli. Plant Cell Tissue Organ Cult. 2018, 134, 423-432. [CrossRef]

102. Harrison, P.J.; Hurd, C.L. Nutrient Physiology of Seaweeds: Application of Concepts to Aquaculture. Cah. Biol. Mar. 2001, 42, 71-82.

103. Oliveira, S.R.M.; Nascimento, A.E.; Lima, M.E.P.; Leite, Y.F.M.M.; Benevides, N.M.B. Purification and Characterisation of a Lectin from the Red Marine Alga Pterocladiella capillacea (S.G. Gmel.) Santel. \& Hommers. Rev. Bras. Bot. 2002, 25, $397-403$.

104. Oliveira, A.S.; Lossio, C.F.; Rangel, A.J.; Martins, M.G.Q.; do Nascimento, F.E.P.; de Andrade, M.L.L.; Cavada, B.S.; Lacerda, S.R.; do Nascimento, K. Detection, Purification and Characterization of a Lectin from Freshwater Green Algae Spirogyra spp. An. Acad. Bras. Ciênc. 2016, 89, 2113-2117. [CrossRef] 